\section{Framework programme poses political questions}

Iт began to emerge clearly last week that the scale of the European Commission's new "framework programme" of cooperative research and development in Europe is so large that a phase of real interaction between international and national research policies in Europe is now beginning, with national programmes the likely "losers" as research becomes more international.

This internationalization of science seems to be becoming a particular possibility in Britain, where technology minister, Mr Geoffrey Pattie, said last week that he had "no trouble" with the content of the European Commission's 1987-91 "framework programme", the definitive version of which the Commission should place before member states in the next few weeks.

Pattie's support, though qualified when it comes to matters of scale, is significant because, in line with Britain's current presidency of the European council of ministers, Pattie will preside for the next six months over the research council. And Britain attaches "considerable importance" to concluding political negotiations over the content and financing of the programme by the end of this year, Pattie says.

Pattie is concerned, however, at the possible cost of the programme (earlier this year, the Commission was seeking a near tripling of present spending from the present 4,300 million European Currency Units'); he demands more critical preassessment and analysis of Commission projects and says a final decision on funding may go to cabinet level.

In fact, Pattie's concern reflects the wider issue: that the levels of research spending recommended by the Commission are at last reaching a politically noticeable level. From around 2 per cent of member states' net research and development budgets, the Commission has moved in its framework programme to nearer 4-6 per cent. In individual projects, the levels are even higher: in materials science, for example, where European national spending lags far behind that of the United States and Japan, initial Commission spending proposals in the framework programme reached a fifth of all European research. This seemed to be going well beyond the mere "catalysis" of European collaboration for which the European Commission has previously argued; and at these levels it has begun to be difficult even for enthusiasts of European collaboration - like Mr Pattie - to argue that European research programmes should not substitute for national research, but add to it. Increases in European programmes are in danger, in Britain at least, of causing reductions in corresponding national ones.

Thus, in money-conscious Britain, where many of the financial issues are clearest, Treasury sources stress that ministries benefiting from any substantial increase in Commission research funding by winning grants - will have to account for these receipts, and may have their national support commensurately reduced. This near-automatic system of "attribution" of Commission receipts could affect a number of national programmes, not least because British researchers appear to be particularly effective at winning Commission support: last year, Britain won 27 per cent of available Commission research funding, although the country pays only 20 per cent of the Commission's total budget. In research, Britain's receipts exceed "juste retour".

Paradoxically, however, this success of British scientists in winning funds from Brussels could in future be penalized by Treasury insistence on the attribution of receipts. Increases under the framework programme could thus conflict with the research of the Department of Energy, and particularly of the Department of Trade and Industry. The Commission's plan to boost its pilot-scale "stimulation programme" - which has successfully combined basic research groups in joint research throughout Europe - could result, under the Treasury attribution rules, in a commensurate decrease in the funds of the research councils, or the universities directly. Sir David Phillips, who is both chairman of the Advisory Board for the Research Councils (which distributes basic research funding in Britain) and a member of the CODEST scientific committee which advices the Commission on science policy, admits that "a key question" now is how far, and whether, national budgets should be cut to support European cooperation. This is why Pattie considers that finding the money for the framework programme may become an issue for the whole government.

The Treasury itself remains unconvinced by the Commission's arguments for an increase in research, and opposes Pattie's view that the framework should not substitute for national programmes. Pattie himself feels he unfortunately gets little help from the Commission - which however important the programmes proposed tends to argue by exhortation.
More detailed and precise arguments are necessary, Pattie says. The framework programme itself should therefore include an important element of assessment to ensure and detail the "effectiveness" and "relevance" of projects and to sharpen arguments for ministers.

Despite the drive for "effectiveness" of the framework programme, however, "flat out market considerations cannot be the order of the day", Pattie insists, because the research-oriented framework programme must take into account the needs of the smaller countries in Europe. These have felt neglected by the quite separate (non-Commission) Eureka technology programme, in which market forces are to the fore. But framework research should have a long-term relevance to European technological competitiveness. An increase in industrial participation, on a sliding scale, as Commission research projects developed, would sharpen Commission programmes Pattie suggested. It would help "to keep testing out the project on industry" and to "make people shape up".

Robert Walgate

\section{German universities}

\section{Hamburg}

In the past fifteen years, federal and Länder (regional) governments have spent DM38,000 million to create an extra 300,000 places at West German universities. But the era of expansion is now near its end, according to the commission for university building.

In its sixteenth framework plan, published last week, the commission recommends that a further DM9,000 million be spent between now and 1990 . High priority is given to the extension of natural science and engineering faculties, among them a new faculty of informatics in Karlsruhe, the next phase of the new Biozentrum in Würzburg and a new centre for interdisciplinary research in Frankfurt. The greater part of the money, however, will go for medical institutions and clinics.

The Federal Minister of Education, Dorothee Wilms, emphasized that the goal of 850,000 university places had not yet been reached, but would be brought close with the creation of another 20,000 places in the near future. Although there are now signs of a downward trend in the number of students entering university, there are still around $\mathbf{1 . 3}$ million students, far more than there are places. Students have grown accustomed to overcrowded lecture theatres without room even to sit on the floor and inadequate library and laboratory space. As the deputy commission head, Anke Brunn, pointed out, there is no sign of the feared "education catastrophe", the collapse of education due to excess student numbers.

Jürgen Neffe 